\title{
MEDALE I MONETY POŚWIĘCONE ŚWIĘTEMU JANOWI PAWLOWI II W KONTEKŚCIE WSPÓLCZESNEGO POLSKIEGO RYNKU DZIEL MEDALIERSKICH I NUMIZMATYCZNYCH
}

\begin{abstract}
Streszczenie
Wśród osób tworzących rynek monet i medali we współczesnej Polsce są wykwalifikowani kolekcjonerzy, posiadający zgłębioną wiedzę o pozyskiwanych obiektach, inwestorzy lub też przypadkowi zbieracze. Szczególne emocje podczas zakupu dzieł do kolekcji budzą monety i medale poświęcone św. Janowi Pawłowi II, których cena nabycia często przekracza rzeczywistą wartość przedmiotu. Miejsc, w których można kupić te przedmioty, jest wiele: sklepy stacjonarne lub internetowe, aukcje, giełdy i targi staroci, instytucje kościelne lub bezpośrednio u autora projektu. Mennica Polska, jako najbardziej prestiżowa instytucja produkująca monety i medale w kraju, dysponuje sklepem stacjonarnym. Wskazany jest zakup przedmiotów w możliwie najlepszych stanach zachowania. Wśród kolekcjonerów popularne są niezmiennie monety i medale dawnej Polski. Zbierane są grupy tematyczne jak: II wojna światowa, flora i fauna czy Jan Paweł II. Zainteresowaniem cieszą się również numizmaty emitowane za granicą. Do nowych trendów kolekcjonerstwa zaliczyć można pozyskiwanie monet obiegowych w doskonałych stanach zachowania, a także tzw. destruktów menniczych (monety błędnie wybite). Kolekcjonerzy większą uwagę zwracają na wartość rynkową przedmiotu, tematykę, niski nakład, kruszec, z którego je wykonano, niż na walory estetyczne, stąd unikatowe tzw. medale autorskie można nabyć za kwoty nieprzekraczające kilkuset złotych.
\end{abstract}

* Dominik Maiński - dr historii; mgr historii sztuki; Biblioteka Uniwersytecka Katolickiego Uniwersytetu Lubelskiego Jana Pawła II; e-mail: dominik.mainski@gmail.com https://orcid.org/0000-0002-8220-3332 
Pomoc w kompletowaniu zbioru stanowią liczne katalogi i cenniki, także dotyczące tematu papieskiego. W literaturze naukowej brak jest opracowań analizujących ikonografię monet i medali oraz ich warstwę stylistyczną.

Słowa kluczowe: moneta; medal; medal autorski; numizmatyka; medalierstwo; kolekcjoner; zbieracz; Jan Paweł II; mennica; woreczki mennicze; destrukty mennicze

Istnieje kilka grup współczesnych kolekcjonerów czy zbieraczy monet i medali. $Z$ jednej strony mogą to być znawcy, którzy biorą udział w wydarzeniach o charakterze wystawienniczym lub naukowym, jak konferencje o tematyce oscylującej wokół zagadnień numizmatyki i medalierstwa. Zazwyczaj osoby te piszą również specjalistyczne teksty. Obok funkcjonują inwestorzy, dla których najistotniejszy jest aspekt materialny gromadzonych przedmiotów. Naturalne jest, że posiadają oni pogłębioną wiedzę, która nie dotyczy zazwyczaj strony estetycznej lub ikonograficznej dzieł, a bardziej warstwy technicznej i informacji o charakterze katalogowym. Ostatnią grupę stanowi rzesza przypadkowych zbieraczy, którzy rozpoczynają przygodę $\mathrm{z}$ kolekcjonerstwem od kompletowania powszechnie dostępnych monet czy medali. Te pobudki mają niekiedy charakter emocjonalny, jak w przypadku okazjonalnych zbieraczy przedmiotów dotyczących Jana Pawła II. $\mathrm{Z}$ czasem te zainteresowania mogą przerodzić się w bardziej wyrafinowane zajęcie. Zazwyczaj na początku gromadzi się wszystko, bez profilowania zbioru do grupy monet czy medali, które łączyłaby pewna wspólna cecha, jak np. okres w mennictwie lub medalierstwie, tematyka czy typ. Stąd te zespoły odznaczają się przede wszystkim chaosem tematycznym.

Dawne monety produkowane w Polsce lub za granicą oraz odlewane albo wybijane medale cieszą się niezmienną popularnością wśród kolekcjonerów. Pożądane są szczególnie obiekty powstałe w znikomym nakładzie i w jak najlepszym stanie zachowania. Niektóre $\mathrm{z}$ takich dzieł znajdują się prawie wyłącznie w zbiorach o charakterze muzealnym, a kiedy pojawiają się na rynku, wywołują szczególną atencję u zbieraczy. Nie można wyodrębnić konkretnych trendów zainteresowania tematyką przedstawień na powierzchni monet w przypadku numizmatów z okresu panowania królów czy czasu zaborów. Ich treść i ikonografia są zazwyczaj podobne i powtarzają się schematycznie w każdej kolejnej epoce. Poza obligatoryjnymi napisami określającymi godność władcy i datą emisji ukazywany był głównie wizerunek panującego (na awersie) i godło ziem, którymi rządził (na rewersie). Treść w medalierstwie jest przeważnie bogatsza. Obok portretu pojawiają się motywy ilustrujące zasługi monarchy na różnych obszarach jego działalności - politycznej, społecznej czy budowniczej. Treść mogą uzupełniać symbole lub alegorie. Na poszczególne zbiory prywatnych kolekcjonerów składają się zatem grupy dzieł dotyczących konkretnych epok w historii wyznaczonych latami panowania danego władcy.

Kolekcje mogą zawężać się do monet o określonym nominale lub też pieniądza albo medalu powstałego na danym obszarze. I tak zbieracze gromadzą np. średniowieczne denary, pieniądze Wolnego Miasta Gdańska lub medale czczące poszczególnych carów. Biorąc pod uwagę monety średniowieczne 
czy nawet antyczne, nie należy zapominać, że wśród nich dominują pieniądze powstałe w znacznych nieraz nakładach, co powoduje, że nie są one atrakcyjne dla wyrafinowanych kolekcjonerów. Przykładem mogą być srebrne denary Trajana $\mathrm{z}$ portretem władcy na awersie $\mathrm{i}$ wizerunkami różnych rzymskich bogiń na rewersach lub też trojaki Zygmunta III Wazy wydane w Krakowie'. Zainteresowanie, które w ostatnich latach przeżywa renesans, dotyczy monet carskiej Rosji. Na wysokość cen ma wpływ pasja numizmatyczna bogatych Rosjan, którzy za upatrzone obiekty są w stanie zapłacić każdą kwotę. Zbieracze wykupują nawet popularne ruble Mikołaja II, których nakład sięga wielu milionów sztuk. Nabywcę znajdzie również moneta w złym stanie zachowania.

Po II wojnie światowej rodzimy rynek kolekcjonerski poszerzył się o nowe pola zbieractwa. Zadaniem Narodowego Banku Polskiego jako emitenta monet jest utrwalanie w świadomości i pamięci społecznej istotnych wydarzeń historycznych i ważnych dla narodu postaci. Równolegle więc do emisji pieniądza o wymiarze czysto użytkowym, funkcjonującego w powszechnym obiegu, wybija się monety okolicznościowe, także $\mathrm{z}$ zastosowaniem różnych kruszców i w ograniczonych nakładach. Pierwszy raz po wojnie pieniądz pamiątkowy wyemitowano w 1964 $\mathrm{roku}^{2}$. Wydano wówczas dwie dziesięciozłotówki $\mathrm{z}$ wizerunkiem Kazimierza Wielkiego (jedna $\mathrm{z}$ napisem wklęsłym, a druga $-\mathrm{z}$ wypukłym) $\mathrm{z}$ okazji 600-lecia Uniwersytetu Jagiellońskiego. Rozpoczęły one liczne emisje serii okolicznościowych monet obiegowych. W niedługim czasie NBP podjął decyzję o zapoczątkowaniu produkcji pieniądza przeznaczonego głównie dla zbieraczy. Za pierwszą monetę tzw. kolekcjonerską uważa się stuzłotówkę z 1966 roku, przedstawiającą postaci Mieszka I i Dąbrówki en face 3 . Pewna część monet o charakterze okolicznościowym od czasów PRL bita jest stemplem lustrzanym. Mennica Polska w Warszawie produkuje takie pieniądze od 1972 roku, kiedy to nastąpiła emisja pięćdziesięciozłotówki z portretem Fryderyka Chopina, która zapoczątkowała serię Wielcy Polacy. Pod względem prawnym wszystkie wspomniane monety są legalnym środkiem płatniczym. Monety lustrzane cechują się chemicznie zmatowionym wizerunkiem i perfekcyjnie wypolerowanym tłem. Walory estetyczne tych przedmiotów polegają na wyrazistości obrazu i kontraście między przedstawieniem a tłem. Specjaliści podkreślają, że monety lustrzane powinny być zachowane w stanie idealnym, aby ich wartość nie została radykalnie obniżona. W celu zabezpieczenia przed zarysowaniami i nieestetyczną patyną (utlenianiem w przypadku srebra) monety pakowane są w specjalne plastikowe kapsle oraz etui i tak sprzedawane w oddziałach NBP. Instytucja systematycznie emituje monety okolicznościowe w srebrze i złocie z użyciem stempla lustrzanego. Obecnie dominuje w mennictwie tendencja do wprowadzania nowatorskich technologii zdobniczych. Wydawane są monety o różnych kształtach (np. wachlarza, wieloboku), z użyciem oryginalnych materiałów jak: ceramika,

${ }^{1} \mathrm{Z}$ kolei do szczególnie pożądanych należą np. trojaki wydane w Mennicy Lubelskiej w ostatnich kilku latach XVI i na początku XVII wieku.

${ }^{2}$ Zarządzenie Ministra Finansów z 18 marca 1964 roku (H. Wojtulewicz, Monety i medale polskie. Informator do wystawy, Muzeum Okręgowe w Lublinie, Lublin 1975, s. 31).

${ }^{3}$ A.S. Nartowski, Złote pożegnanie, „Gazeta Bankowa”, (2004) nr 51, s. 26. 
szkło, hologram. Powierzchnię monet pokrywa się emalią lub podmalowuje tampondrukiem. Medale współczesne emitowane na zamówienie podlegają również rewolucyjnym modom, choć $\mathrm{w}$ ich przypadku projektanci pozostają bardziej powściągliwi. Nowatorsko zdobione produkty są atrakcyjne estetycznie i z tego powodu chętnie kupowane. Kolekcjonerzy starych numizmatów często nie uznają z kolei tych współczesnych za w pełni wartościowe. Kontrowersje budzi także pakowanie monet przez wyspecjalizowane firmy w plastikowe slaby, nazywane przez niektórych zbieraczy „trumienkami”. Z jednej strony działanie to zabezpiecza przedmiot, z drugiej natomiast uniemożliwia bezpośredni z nim kontakt. Taki ogląd obiektu jest szczególnie ważny w przypadku specjalistycznych badań numizmatycznych. Bez względu na niechęć niektórych ekspertów czy kolekcjonerów wobec monet współczesnych, należy się tym przedmiotom uznanie, a ich zbieraczom szacunek. Jak w każdej epoce menniczej emitowane były pieniądze zgodnie $\mathrm{z}$ dostępnymi technologiami, a także według mody lub panujących ówcześnie zasad $\mathrm{w}$ doborze treści i motywów ikonograficznych. W każdym przypadku monety są odzwierciedleniem czasów, w których powstały. Nie bez powodu w okresie Polskiej Rzeczpospolitej Ludowej pierwsze z nich produkowano w tanim aluminium. W czasach powojennych brakowało droższych metali. Pieniądze te nie były wybijane precyzyjnie, co niekorzystnie wpływało na ich wygląd. Ikonografia, treść i ciekawy dobór propagandowych motywów w mennictwie okresu Polski Ludowej spowodowały, że monety, także lustrzane, stanowią jednak doskonały dokument epoki i źródło do badań historycznych. Dopiero od kilku lat pieniądze te cieszą się, jeśli nie uznaniem naukowcównumizmatyków, to coraz większym zainteresowaniem kolekcjonerskim. Mennictwo współczesne bazuje z kolei przede wszystkim na produkcji monet lustrzanych oraz używaniu nowatorskich technik. Zapomina się także często, że dzieła te są projektowane przez wybitnych polskich artystów zatrudnionych w Mennicy Polskiej, spośród których część jest znana na świecie i nagradzana prestiżowymi wyróżnieniami, jak Robert Kotowicz czy Urszula Walerzak. To powoduje, że polskie pieniądze współczesne stają się małymi dziełami sztuki. Niechęć wobec uznania monet tego typu za przedmioty wartościowe, nie tylko materialnie, zwłaszcza przez niektórych specjalistów z dziedziny numizmatyki, stawia pod znakiem zapytania ich wiedzę i wyklucza z grona ekspertów. Za granicą nie lekceważy się zbieraczy najnowszych monet ${ }^{4}$. Prawdziwy numizmatyk to specjalista, który pojęcie wartościowej monety czy medalu rozumie szeroko, nie tylko jako mniej lub bardziej atrakcyjną estetycznie pracę z określonym zestawem znaków i motywów przedstawieniowych, ale również jako odzwierciedlenie epoki historycznej, gdzie objawiają się także mody stylistyczne i osiągnięcia technologiczne. Na rynek hobbistów składa się grupa wyrafinowanych kolekcjonerów starych numizmatów, ale także niemała rzesza przypadkowych zbieraczy, których zainteresowanie powszechnie dostępnymi monetami z czasem może przerodzić się w specjalistyczne poszukiwania oparte na głębokiej wiedzy.

\footnotetext{
${ }^{4}$ Rorys, Z lotu czarnego ptaka, „Przegląd Numizmatyczny”, (2006) nr 2, s. 15.
} 
W ostatnich kilkudziesięciu latach zdarzyło się kilka momentów wyjątkowego zainteresowania kolekcjonerów konkretnymi emisjami. Można wspomnieć o nieracjonalnym zachowaniu zbieraczy po pojawieniu się pierwszych monet okolicznościowych ilustrujących postać Jana Pawła II z 1982 i 1987 roku. Monety były w zamierzeniu skierowane do szerokiego kręgu odbiorców, którzy czekali na te emisje. W polskiej prasie codziennej lat 80 . i początku lat 90. zeszłego stulecia mnożyłysięszokującedoniesieniaohorrendalnychkwotach,zajakiejesprzedawano. Zgodnie z wykazem cen ze stycznia 1991 roku w sklepach kolekcjonerskich można było kupić monetę o nominale 1000 złotych za 60000 złotych, natomiast tę o nominale 10000 złotych - za 80000 złotych $^{5}$. Były one również dostępne w oddziałach bankowych. Tymczasem owe pieniądze często sprzedawano za kwoty sięgające miliona złotych lub kilku tysięcy dolarów. Zdarzały się również przypadki wymiany tzw. papieży za samochody ${ }^{6}$. Ceny katalogowe polskich monet papieskich w okresie od października 1989 roku do końca 1990 roku wzrosły od 20 do $50 \%{ }^{7}$. Natomiast ceny w punktach dystrybucji bankowej zasadniczo się nie zmieniły. Zarząd Polskiego Towarzystwa Archeologicznego i Numizmatycznego postanowił $\mathrm{w}$ prasie zdementować wszelkie spekulacje, określając rzeczywistą wartość przedmiotów ${ }^{8}$. Powodów tego niewyjaśnionego zjawiska doszukiwano się w błędnym utożsamieniu zwykłych monet okolicznościowych ze złotymi numizmatami z rzadkiego zestawu wybitego w Szwajcarii na zlecenie zagranicznej firmy ${ }^{9}$. Okazuje się, że dosyć częste wśród mało doświadczonych kolekcjonerów jest przecenianie wartości monet, które wydają się być obiektami tajemniczymi, unikatowymi, a z tego powodu wyjątkowo cennymi ${ }^{10}$. Dla zbieraczy, zwłaszcza tych zamożnych, charakterystyczne jest z kolei pozyskiwanie przedmiotów za wszelką cenę i gotowość do przepłacania. Częstym powodem kolekcjonerstwa jest fascynacja historią, która - zwłaszcza w czasie początków pontyfikatu Jana Pawła II i jego kolejnych wizyt w ojczyźnie - tworzyła się na oczach Polaków. Należy też zauważyć, że w dobie komunizmu tematy religijne stały się modne wśród wszelkiego rodzaju zbieraczy. Ta ogólna tendencja sprzyjała kolekcjonowaniu zwłaszcza pamiątek papieskich, a wśród nich monet lub medali o tej tematyce.

W ostatnich latach kilka emisji monet okolicznościowych NBP spotkało się także z olbrzymim zainteresowaniem społecznym. Wydaniom niektórych monet towarzyszyły niebotyczne wręcz kolejki ustawiające się przed siedzibami

5 ,Maluch” za monetę z papieżem? Oszustwo!, „Dziennik Wieczorny” [Bydgoszcz], 32 (1991) nr 20, 29 stycznia, s. 5.

${ }^{6}$ Można przytoczyć kilka autentycznych ogłoszeń prasowych tamtego czasu: „Sprzedam srebrną monetę z papieżem $1000 \mathrm{zł} \mathrm{za} 7 \mathrm{ml}$. zł...”, „Zamienię monety z papieżem na domek jednorodzinny...” - cyt. za: T. Sączek, „Monetę z papieżem sprzedam...”, „Magazyn Numizmatyczny” [Oddział PTN w Częstochowie], 1991, nr 6, s. 22.

${ }^{7}$ A. Nowaczyński, Sprzedam „Papieża”..., „Twój Anons” [Bydgoszcz], 1 (1991), 31 stycznia, s. 8.

${ }^{8}$ B. Szymańska, Gorązka monety papieskiej. Ile jest naprawdę warta, „Express Bydgoski”, 2 (1991) nr 12, 17 stycznia, [bez numeracji stron].

${ }^{9}$ Nowaczyński, Sprzedam „Papieża”, s. 8.

${ }^{10}$ J. Doliński, ABC numizmatyka, Warszawa 1971, s. 5. 
Narodowego Banku Polskiego, często także awantury i przepychanki. W pamięci osób interesujących się numizmatyką zakorzeniła się zwłaszcza emisja srebrnej monety o nominale 20 złotych Sokót wędrowny, która 16 stycznia 2008 roku przyciągnęła pod oddziały NBP rzesze chętnych już w nocy poprzedzającej otwarcie banku ${ }^{11}$. Powodem była zapewne popularność i szybki wzrost cen monet o tematyce zwierzęcej. Atmosferę podsycał fakt, że już w dniu emisji na aukcjach internetowych cena kilkakrotnie przewyższała wartość emisyjną monety ${ }^{12}$. W niektórych miejscach $\mathrm{w}$ Polsce przed lokalnymi siedzibami NBP musiała interweniować policja i straż miejska. Tymczasem istniała możliwość uniknięcia konieczności stania w kolejce w celu nabycia monety. Korzystnym rozwiązaniem mógł być zakup abonamentu numizmatycznego, co oferowała większości sklepów numizmatycznych w Polsce ${ }^{13}$. Dawało to gwarancję pozyskania kolejnych monet kolekcjonerskich po cenach emisyjnych. Na tle opisywanych wydarzeń z początkiem 2010 roku Narodowy Bank Polski wprowadził nowe zasady dystrybucji srebrnych i złotych monet oraz banknotów okolicznościowych poprzez aukcje internetowe w specjalnym serwisie „Kolekcjoner”. W ostatnim latach powrócono do starych zasad dystrybucji, według których monety można kupować swobodnie w kasach NBP lub w jego sklepie internetowym. Na rynku monet najnowszych nastąpił spokój i zrównoważenie cen. Mimo to bywają emisje, które powodują wyjątkowe zainteresowanie. Do takich należała seria dzieł wybitych z okazji kanonizacji Jana Pawła II w 2014 roku, która ponownie zgromadziła chętnych w długich kolejkach przed oddziałami NBP. Szczególnie pożądana była srebrna moneta o nominale 500 złotych i niespotykanej dotąd wadze jednego kilograma.

Innym ciekawym zagadnieniem współczesnego rynku numizmatycznego jest zbieranie pieniędzy obiegowych, również obecnie używanych, zgodnie z datami emisji. Popularnością cieszą się monety z okresu PRL-u, głównie te wybite $\mathrm{w}$ aluminium i w rzadszym nakładzie. W związku z miękkim metalem, mało odpornym na przetarcia na rynku monety aluminiowe zachowane w stanie bezobiegowym należą do rzadkości, co wpływa na ich wysoką cenę. Firmy zajmujące się produkcją akcesoriów dla zbieraczy dystrybuują specjalne albumy przeznaczone dla monet $\mathrm{z}$ kolejnych lat emisyjnych. Przykładem sa albumy rocznikowe dla monet obiegowych z okresu Polskiej Rzeczpospolitej Ludowej lub też zaprojektowane do przechowywania monet okolicznościowych o nominale 2 złote wykonanych ze stopu nordic gold (CuAl5Zn5Sn1). Emisja tych ostatnich została wstrzymana w 2014 roku na rzecz monet tematycznych o nominale 5 złotych, wybijanych w tym samym formacie co zwykłe obiegowe pięciozłotówki. Polityka emisyjna NBP, w dużej mierze nastawiona komercyjnie, w tej kwestii jest niezrozumiała, gdyż dwuzłotówki cieszyły się wyjątkową

${ }^{11}$ E. Dąbrowska, Abonament numizmatyczny. Zysk dla przewidujacych, „Investment Tribune”, (2008) nr 9, s. 26. Przed bankiem prowadzone były zapisy do kolejki na listach.

${ }^{12}$ Sprzedaż monet ruszyła już przed dniem emisji i była prowadzona przez zarejestrowane firmy numizmatyczne, które na podstawie umów z NBP miały zapewnioną odpowiednią partię monet.

${ }^{13}$ Dąbrowska, Abonament numizmatyczny, s. 26. 
popularnością wśród zbieraczy, zwłaszcza tych mniej zamożnych, których było stać na zgromadzenie pełnego zestawu 260 monet. Od kompletowania tego typu pieniędzy niektóre osoby rozpoczynały swoją przygodę z kolekcjonerstwem.

Gwarancją idealnego stanu zachowania jest zakup współczesnych obiegówek dystrybułowanych w tzw. woreczkach menniczych. Monety pakowane są w Mennicy Polskiej zazwyczaj po 100 sztuk w plastikowe torebki opatrzone nazwą przedsiębiorstwa. Woreczki można kupić w oddziałach NBP w całej Polsce, choć od pewnego czasu instytucja wstrzymała dystrybucję w takiej formie monet o nominałach 1, 2 i 5 groszy. Najdroższą monetą obiegową ze stopu nordic gold jest dwuzłotówka z 1996 roku z portretem Zygmunta II Augusta. Obecnie egzemplarz w stanie idealnym można kupić za ok. 400 złotych. Łatwo więc policzyć, że na rynku kolekcjonerskim woreczek takich monet jest wart 20 tys. złotych, podczas gdy jego wartość nominalna to jedynie 100 złotych ${ }^{14}$. Oczywiście w obrocie handlowym takie woreczki należą do rzadkości, gdyż większość z nich od czasu emisji została rozpakowana, aby monety mogły trafić do obiegu.

Do specyficznej dziedziny z kręgu numizmatyki należą również tzw. destrukty mennicze. Są to błędnie wybite monety. W Polsce monopol na produkcję monet, czyli metalowego środka płatniczego o określonym nominale, ma Mennica Polska. Jest też głównym twórcą medali. Przedsiębiorstwo dysponuje najnowocześniejszymi technologiami i maszynami menniczymi na świecie, co - obok udziału w projektowaniu monet wybitnych polskich artystów gwarantuje precyzję na najwyższym poziomie. Niejednokrotnie Mennica Polska była nagradzana podczas międzynarodowych konkursów na najpiękniejsze lub najbardziej zaawansowane technicznie monety. Poza tym w instytucji stosuje się wieloetapowy proces weryfikacji produktu. Stąd destrukty należą do rzadkości. Błędy powstają $\mathrm{w}$ trakcie przygotowywania krążka dla przyszłej monety. Zdarzają się więc egzemplarze o brakującym fragmencie lub o rozchodzących się elementach $-\mathrm{w}$ przypadku tzw. monet bimetalicznych (np. wykonane $\mathrm{z}$ dwóch metali monety obiegowe o nominale 2 złote). Usterki powstają również w trakcie wybijania, gdy stempel krzywo uderzy w źle ustawiony w maszynie krążek. Wtedy obraz na monecie jest przesunięty i wybiega poza obrys przedmiotu. Stempel może być też zapchany, co powoduje, że przedstawienie jest rozmyte. Wydawać by się mogło, że jako produkt zawierający błąd taki egzemplarz powinien być bezwartościowy. Tymczasem stanowi on przedmiot zainteresowania zbieraczy destruktów, którego cena rynkowa wielokrotnie przewyższa wartość nominalną lub emisyjną. Przykładem są błędnie wybite obiegowe pięciozłotówki, które niekiedy pojawiają się w handlu. Krążki do ich produkcji wykonane są z dwóch stopów miedzioniklu (MN25) i brązalu (CuAl6Ni2). Bywa, że krążek wewnętrzny zostanie źle zamocowany w zewnętrznym. Wtedy prawdopodobne jest, że po wybiciu stempla całość ulegnie rozsunięciu, a elementy składowe nałożą się na siebie. W monecie może też powstać otwór, a jej obrzeże zostać zmodyfikowane. Ceny takiego egzemplarza oscylują na poziomie kilkuset złotych, o kilka tysięcy procent przekraczając jego wartość obiegową.

${ }^{14}$ Monety ze stopu nordic gold pakowane były w woreczki po 50 sztuk. 
Wśród zbieraczy jest niewiele osób szczególnie ceniących estetykę dzieł. Monety i medale gromadzone są przede wszystkim ze względu na tematykę, ich unikatowy nakład, rzadki i drogi materiał, z którego je wykonano, np. złoto czy platyna, lub też z powodów inwestycyjnych, gdy wartość monety czy medalu ma tendencję zwyżkową. Tak zwane medale autorskie, które współcześni artyści tworzą jako wynik wewnętrznego impulsu i natchnienia, cieszą się popularnością jedynie wśród nielicznych kolekcjonerów nastawionych na estetykę przedmiotu. Poza oficjalnymi zamówieniami na medale wielkonakładowe, płynącymi ze strony różnego rodzaju instytucji, gdzie dobór motywów przedstawieniowych musi być czytelny i zazwyczaj konsultowany ze zleceniodawcą, artyści tworzą dzieła unikatowe. W dobie obecnych trendów w sztuce tzw. małego reliefu twórcy rezygnują często z klasycznego w medalierstwie realizmu wizerunków na rzecz abstrakcji i ograniczenia figuratywności. Prace takie bywają niezrozumiałe. Ewa Olszewska-Borys - jedna z najwybitniejszych projektantek, notabene medali o przekazie raczej czytelnym -stwierdziła, że wśród współczesnych kolekcjonerów bardziej pożądane są dzieła o charakterze tradycyjnym niż te kształtowane nowatorsko ${ }^{15}$. Medale artystyczne powstają w niewielkiej liczbie egzemplarzy, co dodatkowo wpływa na ich ograniczoną dostępność. Zresztą brak czytelnej treści wiąże się również, zdaniem niektórych specjalistów, z rozbieżnością między ikonografią dzieł małego reliefu a ich tytułami, które nie tłumaczą przekazu, co dodatkowo zniechęca kolekcjonerów ${ }^{16}$. Współczesne medalierstwo, które nie cieszy się zbytnim poważaniem wśród historyków sztuki interesujących się bardziej malarstwem, rzeźbą i architekturą, stanowi dyscyplinę słabo prezentowaną w komercyjnych galeriach. Wspomniane tło powoduje, że ceny medali, mimo nieraz unikatowego nakładu ograniczonego do kilku sztuk, plasują się na poziomie nieprzekraczającym kilkuset złotych, co można zaobserwować na przykładzie aukcji na portalu Allegro. Jest to więc dobry moment do nabywania takich dzieł. Niska cena rynkowa prac autorskich przy dużych kosztach odlewów powoduje, że tworzenie medali jest dla artysty, nawet tego znanego, zazwyczaj nieopłacalne ${ }^{17}$. Do najbardziej znanych projektów autorskich poświęconych osobie Jana Pawła II należą dzieła Józefa Stasińskiego. Ten nestor współczesnego medalierstwa polskiego stworzył serię 27 medali odlewanych corocznie i przypominających ważne momenty pontyfikatu Ojca Świętego. Artysta nawiązał tym sposobem do tradycji medali annualnych emitowanych przez stulecia w Watykanie. Dzieła tego jednego z najwybitniejszych medalierów polskich można na rynku nabyć za kwoty nieprzekraczające 200 złotych.

Niektóre tematy monet okolicznościowych lub medali cieszą się szczególną popularnością. Wśród kolekcjonerów tych drugich można zauważyć dwa

${ }^{15}$ E. Olszewska-Borys, Federacja FIDEM i jej cele, w: Medale i ich twórcy. Sesja z okazji 40-lecia Muzeum Sztuki Medalierskiej 18-19.02.2005, red. A. Borkowska, Wrocław 2005, s. 33.

${ }^{16}$ W. Kabaj, Medalierzy i kolekcjonerzy, Bydgoszcz 1986, s. 4-5.

${ }^{17}$ Wywiad z Katarzyną i Józefem Stasińskimi przeprowadzony przez autora w domu artystów w Poznaniu 29 czerwca 2012 roku, nagranie w posiadaniu autora. 
dominujące nurty zbieractwa ${ }^{18}$. $Z$ chęcią gromadzone są wydawane w Polsce dzieła patriotyczne dotyczące np. II wojny światowej i historii współczesnej oraz medale $\mathrm{Z}$ wizerunkami Jana Pawła II. Sytuacja w przypadku monet wygląda podobnie. $\mathrm{Z}$ dużym zainteresowaniem, co przekłada się na większy pułap osiąganych cen, spotykają się też monety o tematyce zwierzęcej. Z kolei trendy kolekcjonowania monet i medali zagranicznych są niemożliwe do precyzyjnego określenia ze względu na ogrom materiału, zróżnicowanie typów, technik produkcji czy cen. Kolekcjonerzy nastawieni są przeważnie na gromadzenie dzieł z określonych grup tematycznych jak np.: fauna, flora, ekologia, marynistyka, kolejnictwo, sport, kosmos, architektura i technika oraz Jan Paweł $\mathrm{II}^{19}$. Najbardziej popularnym nominałem wśród zbieraczy monet obcych jest euro.

Kilka zasad gwarantuje stworzenie cennej i atrakcyjnej kolekcji. Przede wszystkim warto jest gromadzić produkty prestiżowych instytucji zajmujących się emisją monet i medali, jak np. Mennicy Polskiej, której asortyment plasuje się na światowym poziomie. Zbiory należy zawęzić do konkretnej treści lub typu, aby uniknąć chaosu. Wskazane jest kompletowanie serii tematycznych, co nadaje zespołowi jednolitość. Cena, jaką można osiągnąć za cały zestaw monet lub medali, jest zdecydowanie wyższa niż poziom zsumowanych cen poszczególnych egzemplarzy sprzedawanych osobno ${ }^{20}$. Dodatkowo znacząca jest tu zatem wartość kolekcjonerska, która wynika z trudu pozyskania całości. Warunkiem dobrej inwestycji jest nabywanie monet i medali w najlepszym możliwym stanie zachowania oraz zwracanie uwagi na ich niski nakład. Dobrą inwestycją jest zakup monet lub medali ze szlachetnych metali, głównie złota, którego cena ma przeważnie tendencję zwyżkową, a także numizmatów wykonanych z użyciem oryginalnych technik. Dzieła najbardziej atrakcyjne pod względem wartości artystycznej zawsze znajdą nabywcę.

Dla znawcy tematu jest oczywiste, że moneta lub medal muszą być zachowane w dobrym stanie, aby ich cena plasowała się na zadawalającym poziomie. Rzadko zdarza się, aby dzieła $\mathrm{z}$ minionych epok utrzymały się w tzw. stanie menniczym, nie nosząc śladów użytkowania. Stan taki zapewnia piękny wygląd monety lub medalu, wyrazistość najmniejszych szczegółów i blask tła. Od pewnego czasu monety są sprzedawane w tzw. slabach. Przed zamknięciem przedmiotu w takim plastikowym pudełku następuje wnikliwa ocena jego stanu zachowania przez specjalistę-numizmatyka. Informacje o tym, jak i inne dane (nazwa, nominał, data emisji) widnieją na opakowaniu. Stan zachowania jest określony według wielostopniowych skali. W Polsce kilka firm zajmuje się tzw. gradingiem, czyli nadawaniem monetom oznaczeń stanu zachowania. Należy wymienić Gliwickie Centrum Numizmatyczne (GCN) i Polskie Centrum Gradingu (PCG). Zazwyczaj

${ }^{18}$ W. Zawadzki, Zbiory tematyczne na medalach, „Grosz”, (1990) nr 39, s. 16. Autor doszedł do tych wniosków prawie 30 lat temu, oglądając kolekcje swoich kolegów numizmatyków oraz czytając teksty w jednym ze sztandarowych czasopism medalierskich tamtych lat - „Medalierstwo i Falerystyka". Obecnie tendencje kolekcjonerskie są podobne.

${ }^{19}$ Rorys, Egzotyka, świecidełka, farbowanki... z czym to jeść??, „Przegląd Numizmatyczny”, (2003) nr 2, s. 14.

${ }^{20}$ M. Przybylski, Jak zarobić na kolekcjonowaniu, „Manager”, (2010) marzec, s. 61. 
tak zabezpieczona i opisana moneta podczas transakcji osiąga zdecydowanie większą cenę.

Źródeł nabywania materiału kolekcjonerskiego jest w Polsce wiele. Poza wymianą między zbieraczami monety i medale kupuje się bezpośrednio $\mathrm{u}$ producenta. Mennica Polska dysponuje sklepem stacjonarnym w swojej siedzibie w Warszawie. Monety można także pozyskiwać zgodnie z ceną emisyjną w kasach wszystkich 16 oddziałów NBP. Kolekcjonerzy mogą zaopatrywać się w prywatnych sklepach sprzedających monety, medale i akcesoria numizmatyczne. Do najbardziej znanych należy Antykwariat Numizmatyczny Michała Niemczyka w Warszawie. Można tam nabyć przedmioty unikatowe, nieraz o charakterze muzealnym. Większość ze sklepów ma swoje witryny internetowe oraz oferuje asortyment na portalach aukcyjnych, jak Allegro. Dobrym miejscem do pozyskiwania walorów numizmatycznych są aukcje stacjonarne, a także giełdy kolekcjonerskie albo targi staroci. Pomniejsze wydania medali papieskich można kupować w lokalnych instytucjach kościelnych, a monety zagraniczne poświęcone Ojcu Świętemu - w mennicach państw emitujących. Wskazane jest nabywanie medali autorskich bezpośrednio u artystów. Dzięki temu unika się falsyfikatów, które często pojawiają się na rynku.

Pomocą dla kolekcjonerów jest obszerna literatura, wśród której dominują katalogi czy cenniki monet lub medali. Podają one zazwyczaj w skrótowej formie informacje na temat poszczególnych obiektów, m.in.: lata emisji, nominał, dane techniczne (materiał, waga, rozmiar, próba - w przypadku metali szlachetnych). Najbardziej przydatne są obecnie katalogi-cenniki Janusza Parchimowicza ${ }^{21}$ lub redagowane przez Adama Łanowego ${ }^{22}$. Co do starszych monet warte polecenia są katalogi autorstwa Czesława Kamińskiego lub Janusza Kurpiewskiego (niektóre wydane $\mathrm{w}$ kooperacji tych dwóch numizmatyków) ${ }^{23}$. Najlepsze katalogi-cenniki monet światowych wydawane są w Stanach Zjednoczonych przez Krause Publications ${ }^{24}$. Niewątpliwie najbardziej przydatnym dziełem dla zainteresowanych medalierstwem jest katalog zatytułowany Medale Mennicy Polskiej z 2011 roku $^{25}$, który przybliża dorobek przedsiębiorstwa będącego głównym producentem dzieł małego reliefu w Polsce w XX i XXI wieku. Kolekcjonerzy muszą też korzystać z licznych katalogów medali produkowanych na konkretnym terenie lub związanych $\mathrm{z}$ danym miejscem. Przykładem jest

${ }^{21}$ J. Parchimowicz, Katalog monet polskich obiegowych i kolekcjonerskich od 1916, Szczecin 2019. Jest to katalog wydawany corocznie. Parchimowicz jest autorem także innych katalogów obejmujących różne okresy polskiego mennictwa.

${ }^{22}$ Katalog monet polskich i z Polska zwiazanych XX i XIX wiek. Monety koronne Stanistawa Augusta Poniatowskiego, red. A. Łanowy, wstęp A. Fischer, A. Łanowy, Bytom 2018. Podobnie jak publikacja Parchimowicza jest wydawany co roku.

${ }^{23}$ C. Kamiński, J. Kurpiewski, Katalog monet polskich 1587-1632 (Zygmunt III Waza), Warszawa 1990.

${ }^{24} \mathrm{Na}$ przykład najnowsze wydanie jednego z katalogów: T. Michael, T. Schmidt, R. Giedroyc, 2019 Standard Catalog of World Coins, Iola 2018.

${ }^{25}$ O. Paszkowycz, Medale Mennicy Państwowej 1946-2010/Medals from the Polish State Mint 1946-2010, Łódź 2011. 
wykaz dzieł medalierskich dotyczących Augustowa ${ }^{26}$. Niestety w literaturze brak jest opracowań analizujących walory estetyczne monet lub medali albo ich stronę ikonograficzną, co byłoby przydatne przede wszystkim dla historyków sztuki zajmujących się plastyką małego reliefu. Analizy stylistyczne w ograniczonym wymiarze pojawiają się jedynie we wstępach do katalogów wystaw, zwłaszcza tych, które przybliżają dorobek artystyczny konkretnego medaliera. Medale i monety obrazujące osobę i dzieło Jana Pawła II doczekały się wielu odrębnych katalogów i cenników. Do najbardziej popularnych należy katalog monet wydany kilkakrotnie przez Wydawnictwo „Fischer”27 oraz monumentalny, choć nie pozbawiony licznych błędów, katalog medali opublikowany przez Zbigniewa Nestorowicza ${ }^{28}$.

\section{BIBLIOGRAFIA}

Dąbrowska Eliza, Abonament numizmatyczny. Zysk dla przewidujacych, „Investment Tribune", 2008, nr 9, s. 26-27.

Doliński Jarosław, $A B C$ numizmatyka, Warszawa 1971.

Jan Pawet II na monetach świata, red. A. Łanowy, Bytom 2010.

Kabaj Władysław, Medalierzy i kolekcjonerzy, Bydgoszcz 1986.

Kamiński Czesław, Kurpiewski Janusz, Katalog monet polskich 1587-1632 (Zygmunt III Waza), Warszawa 1990.

Katalog monet polskich i z Polska zwiazanych XX i XIX wiek. Monety koronne Stanistawa Augusta Poniatowskiego, red. A. Łanowy, wstęp A. Fischer, A. Łanowy, Bytom 2018.

„Maluch” za monete z papieżem? Oszustwo!, „Dziennik Wieczorny” [Bydgoszcz], 32 (1991) nr 20, 29 stycznia, s. 1, 4-5.

Medale augustowskie, zbiór i oprac. E. Simson, K. Anuszkiewicz, tekst i opisy hist. J. Bednarczyk, Augustów 2001.

Michael Thomas, Schmidt Tracy, Giedroyc Richard, 2019 Standard Catalog of World Coins, Iola 2018.

Nartowski Andrzej S., Złote pożegnanie, „Gazeta Bankowa”, (2004) nr 51, s. 26-27.

Nestorowicz Zbigniew, Jan Pawet II w medalierstwie polskim, Lublin 2012.

Nowaczyński Andrzej, Sprzedam „Papieża”..., „Twój Anons” [Bydgoszcz], 1 (1991) 31 stycznia, s. 8.

Olszewska-Borys Ewa, Federacja FIDEM i jej cele, w: Medale i ich twórcy. Sesja z okazji 40-lecia Muzeum Sztuki Medalierskiej 18-19.02.2005, red. A. Borkowska, Wrocław 2005, s. 31-35.

Parchimowicz Janusz, Katalog monet polskich obiegowych i kolekcjonerskich od 1916, Szczecin 2019.

Paszkowycz Orest, Medale Mennicy Państwowej 1946-2010/Medals from the Polish State Mint 1946-2010, Łódź 2011.

Przybylski Mariusz, Jak zarobić na kolekcjonowaniu, „Manager”, (2010) marzec, s. 60-61. Rorys, Egzotyka, świecidetka, farbowanki... z czym to jeść??, „Przegląd Numizmatyczny”, (2003) $\mathrm{nr}$ 2, s. 12-14.

${ }^{26}$ Medale augustowskie, zbiór i oprac. E. Simson, K. Anuszkiewicz, tekst i opisy hist. J. Bednarczyk, Augustów 2001.

${ }^{27}$ Jan Pawet II na monetach świata, red. A. Łanowy, Bytom 2010.

${ }^{28}$ Z. Nestorowicz, Jan Pawet II w medalierstwie polskim, Lublin 2012. 
Rorys, Z lotu czarnego ptaka, „Przegląd Numizmatyczny”, (2006) nr 2, s. 14-15.

Sączek Tadeusz, ,, Monetę z papieżem sprzedam ... ”, „Magazyn Numizmatyczny” [Oddział

PTN w Częstochowie], (1991) nr 6, s. 22-24.

Szymańska Bożena, Gorączka monety papieskiej. Ile jest naprawdę warta, „Express Bydgoski”, 2 (1991) nr 12, 17 stycznia, [bez numeracji stron].

Wojtulewicz Henryk, Monety $i$ medale polskie. Informator do wystawy. Muzeum Okręgowe w Lublinie, Lublin 1975.

Wywiad z Katarzyną i Józefem Stasińskimi przeprowadzony przez autora w domu artystów w Poznaniu 29 czerwca 2012 roku, nagranie w posiadaniu autora.

Zawadzki Wiesław, Zbiory tematyczne na medalach, „Grosz”, (1990) nr 39, s. 16-17.
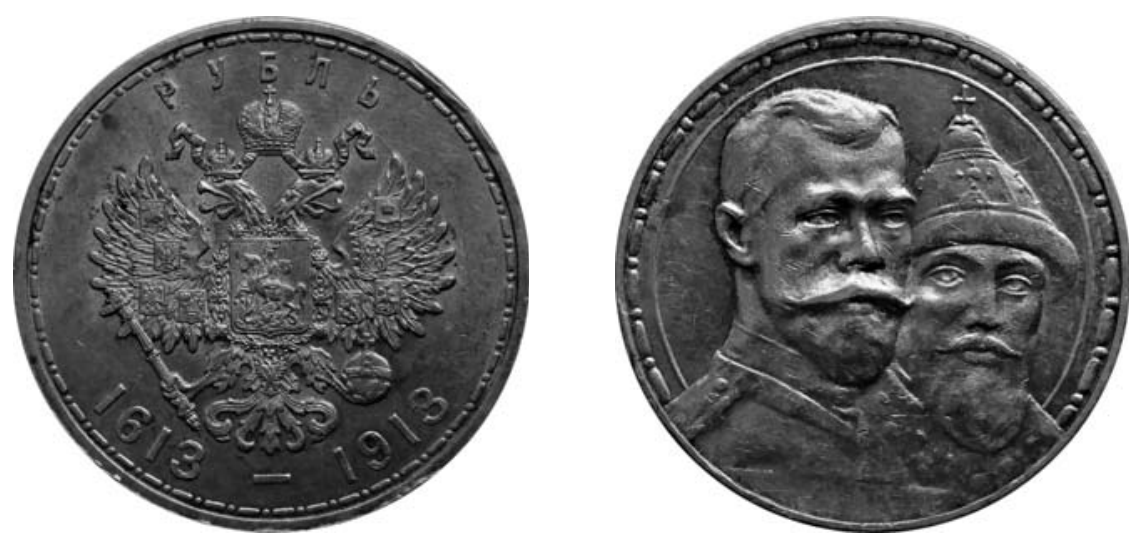

Il.1. 1 rubel, 300 lat dynastii Romanowów, Rosja, 1913, srebro (fot. autora). 

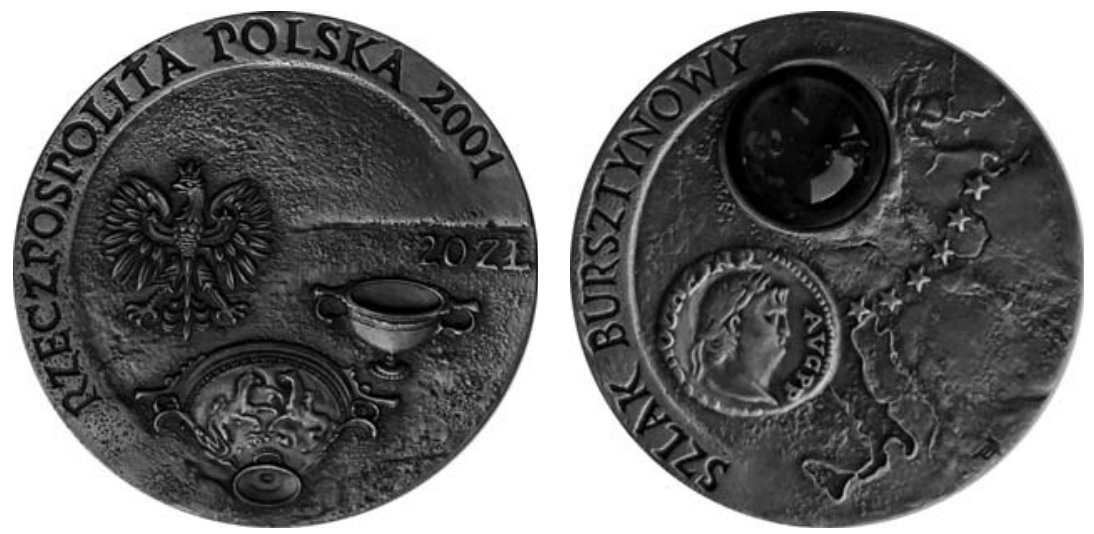

I1.2. 20 złotych, Szlak bursztynowy, 2001, proj. Ewa Tyc-Karpińska, srebro + bursztyn, moneta oksydowana (fot. autora).
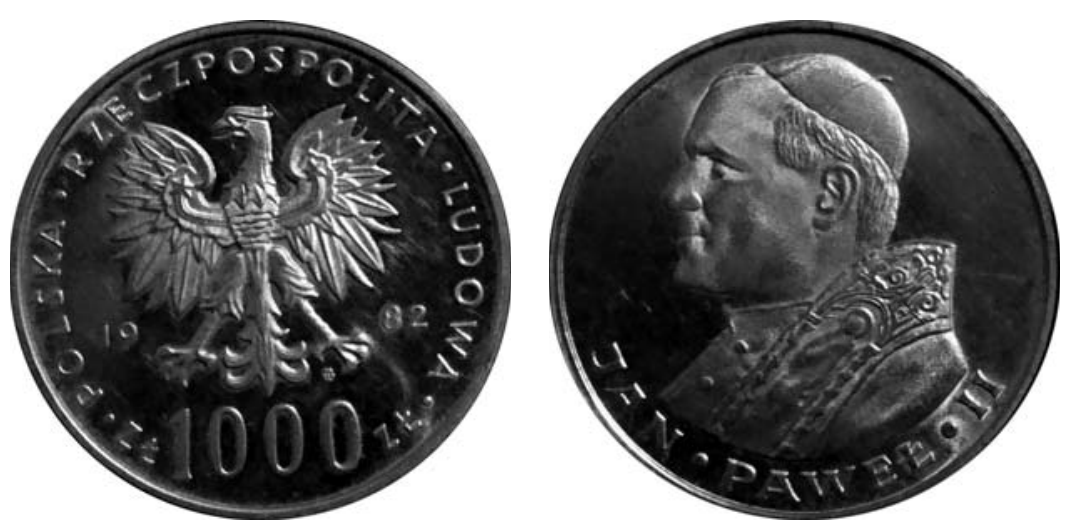

Il.3. 1000 złotych, Jan Paweł II, 1982, proj. Stanisława Wątróbska-Frindt, srebro (fot. autora). 


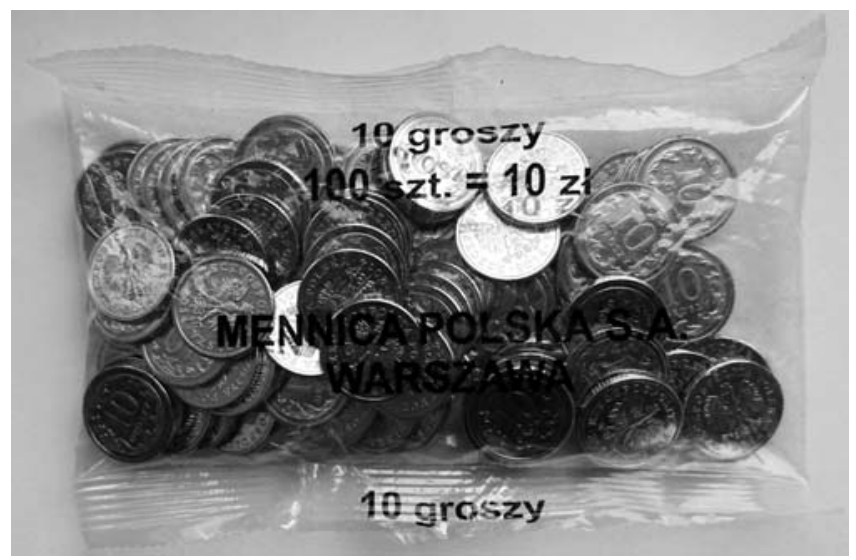

Il.4. Woreczek menniczy, 10 groszy, 2014, proj. Stanisława Wątróbska-Frindt (awers) i Ewa Tyc-Karpińska (rewers), miedzionikiel (fot. autora).
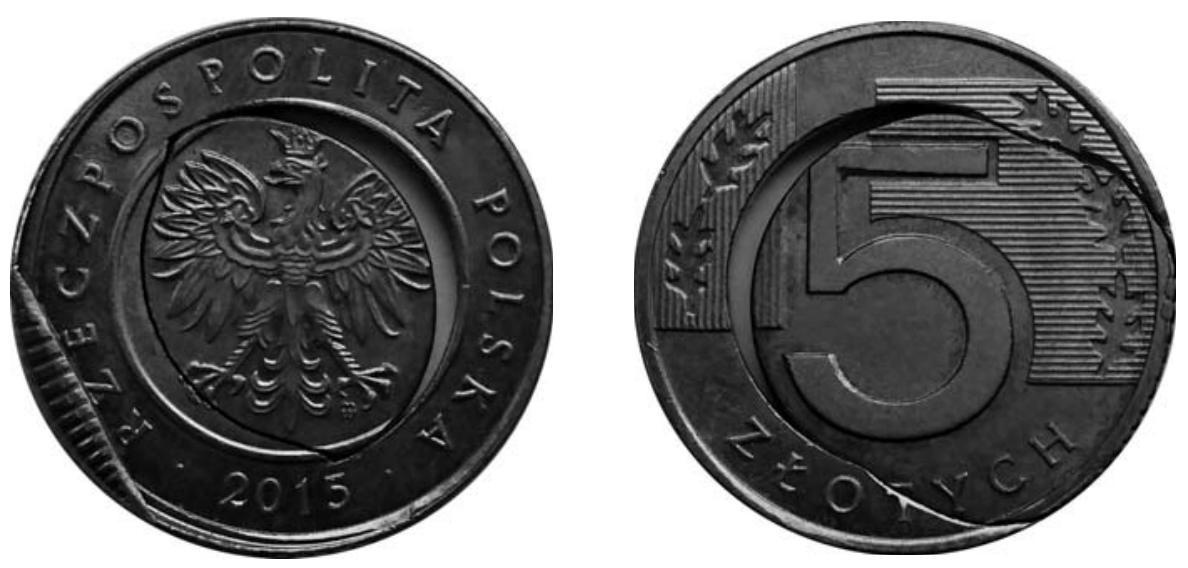

I1.5. Destrukt, 5 złotych, 2015, proj. Ewa Tyc-Karpińska, aluminium $\mathrm{z}$ brązem (brązal) + miedzionikiel

(fot. autora). 


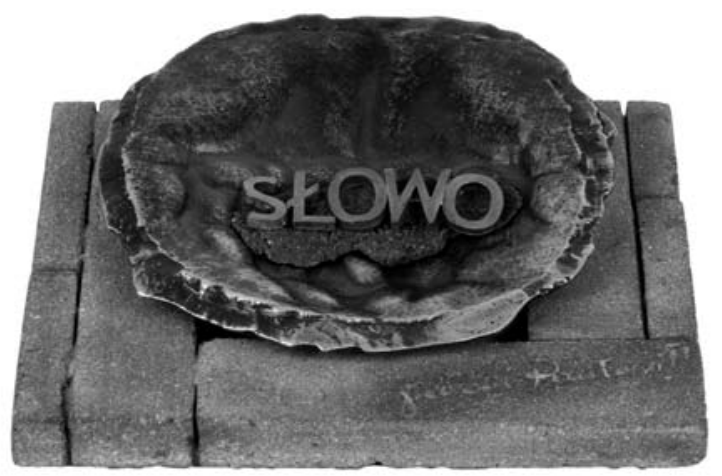

Il.6. Medal, Przesłanie [Janowi Pawłowi II], 2014, proj. Alicja Majewska, brąz, beton, ziemia (fot. Mariusz Berdys; zdjęcie udostępnione przez Bernarda Marka Adamowicza).

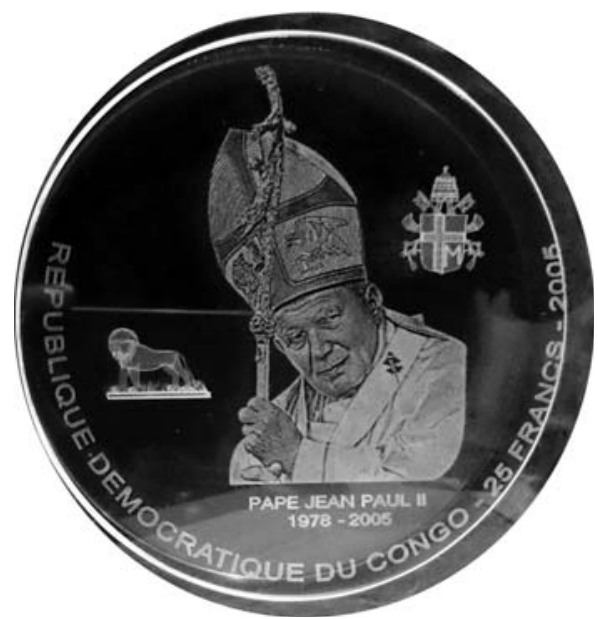

I1.7. 25 franków, Pape Jean Paul II 1978-2005, Kongo, 2005, akryl (fot. autora). 


\title{
THE MODERN POLISH MARKET OF THE MEDALLIC AND NUMISMATIC WORKS. A SPECIAL SIGNIFICANCE OF THE MEDALS AND COINS DEVOTED TO ST JOHN PAUL II
}

\begin{abstract}
Summary
Among people making up the market of coins and medals in contemporary Poland are well-qualified collectors having deep knowledge about acquired objects, investors and casual collectors. Particular emotions are aroused while coins and medals devoted to John Paul II are purchased; their price frequently exceeds the real value of the item. There are a lot of places where you can buy coins and medals: bricks-and-mortar shops, online shops, auctions, markets (including flea markets) and church institutions. These items can also be bought directly from the author of the design. The Polish Mint, as the most prestigious institution producing coins and medals in Poland, has its own bricks-and-mortar shop. It is advisable to buy well-preserved objects. The particularly popular coins among collectors are the old Polish ones. Thematic groups which are collected are as follows: World War II, flora and fauna or John Paul II. There is also a lively interest in coins issued abroad. In addition, there is a new growing trend towards collecting well-preserved circulating coins and mint error coins. Rather than paying attention to coins' artistic values, collectors focus on their market value, the theme, the low number of the issued items and the metal from which they are made, thus the original coins or medals can be purchased for the amount not higher than a few thousand zlotys. Numerous catalogues and price lists, also regarding the papal theme, are helpful materials in compiling the collection. It must be noted that in the literature, there are no monographs analyzing the iconography of coins and medals, and their stylistic features.
\end{abstract}

Key words: a coin; a medal; an original medal; numismatics; medallic art; a collector; John Paul II; a mint, mint money bags; mint error coins 